\title{
Microstructure and mechanical properties of carbon fibre-reinforced alumina composites fabricated from sol
}

\author{
CHAOYANG FAN, QINGSONG MA* and KUANHONG ZENG \\ Science and Technology on Advanced Ceramic Fibers and Composites Laboratory, National University of Defense \\ Technology, Changsha 410073, People's Republic of China \\ *Author for correspondence (nudtmqs1975@163.com)
}

MS received 21 September 2017; accepted 17 October 2017; published online 17 May 2018

\begin{abstract}
Alumina matrix composites reinforced with the laminated and stitched carbon fibre cloth preform were fabricated through the infiltration-drying-heating route using the $\mathrm{Al}_{2} \mathrm{O}_{3}$ sol with a high solid content as raw materials. The investigation was focussed on the characteristics of sol and the mechanical properties and high-temperature resistance of $\mathrm{C} / \mathrm{Al}_{2} \mathrm{O}_{3}$ composites. $\alpha-\mathrm{Al}_{2} \mathrm{O}_{3}$ with favourable sintering activity can be obtained after heat treatment of sol at $1200^{\circ} \mathrm{C}$. The asreceived $\mathrm{C} / \mathrm{Al}_{2} \mathrm{O}_{3}$ composites with a total porosity of $16.8 \%$ exhibit a flexural strength of $271.3 \mathrm{MPa}$ and a notch toughness of $13.0 \mathrm{MPa} \mathrm{m}{ }^{1 / 2}$, respectively. As a result of the evolution of interface and matrix, the flexural strength of $\mathrm{C} / \mathrm{Al}_{2} \mathrm{O}_{3}$ composites is decreased by $28.5 \%$ after heat treatment at $1600^{\circ} \mathrm{C}$ for $1 \mathrm{~h}$ under inert atmosphere. At the same time, fracture mode of composites is transformed from tough to brittle behaviour.
\end{abstract}

Keywords. Alumina; composites; carbon fibre reinforcement; sol; mechanical properties.

\section{Introduction}

Alumina $\left(\mathrm{Al}_{2} \mathrm{O}_{3}\right)$ ceramics have attracted much interest for structural and functional applications owing to outstanding general properties [1-3]. However, brittle fracture problem should be resolved before its wide applications as structural materials. Continuous fibre with outstanding damage tolerance was considered to be the best reinforcement.

So far, oxide fibre was paid the most attention for reinforcing $\mathrm{Al}_{2} \mathrm{O}_{3}$ ceramics [4]. Oxide/ $\mathrm{Al}_{2} \mathrm{O}_{3}$ composites can be used at $1100^{\circ} \mathrm{C}$ for a long time and at $1300^{\circ} \mathrm{C}$ for a short time, which is decided by high temperature resistance of oxide fibre [5]. Due to high price and large diameter of SiC fibre, $\mathrm{SiC} / \mathrm{Al}_{2} \mathrm{O}_{3}$ composites are rarely reported [6,7]. There are not many studies on carbon fibre-reinforced $\mathrm{Al}_{2} \mathrm{O}_{3}$ composites [8-12], although carbon fibre was extensively employed to reinforce non-oxide ceramics. Apart from reaction-bonding aluminium oxide (RBAO) [6,7], sol-gel $[8,11,12]$ and electrophoretic deposition (EPD) [13]; slurry impregnation and heat treatment $(\mathrm{SIH})[4,9,10]$ are dominant routes to prepare fibre-reinforced $\mathrm{Al}_{2} \mathrm{O}_{3}$ composites.

Thanks to flexibility in structure design, desirable comprehensive performance and adaptability to complex shape, three-dimensional (3D) fibre preform was extensively adopted to fabricate composites for applications in astronautic and aeronautic equipments. To prepare $3 \mathrm{D}$ fibre-reinforced $\mathrm{Al}_{2} \mathrm{O}_{3}$ composites, especially large-size complex parts, gas infiltration and solution impregnation are preferred for the sake of homogeneous distribution of matrix and low fabrication temperature. At present, for the deposition of $\mathrm{Al}_{2} \mathrm{O}_{3}$, there is no proper gaseous raw material. As a result of large-size particles i.e., prone to sedimentation, 3D fibre-reinforced $\mathrm{Al}_{2} \mathrm{O}_{3}$ composites with heterogeneous distribution of matrix are fabricated through SIH route at high temperature [10]. When Al-containing solution was selected as a raw material, the transformation efficiency from solution via gel to $\mathrm{Al}_{2} \mathrm{O}_{3}$ is very low, creating $3 \mathrm{D}$ fibre-reinforced $\mathrm{Al}_{2} \mathrm{O}_{3}$ composites with high porosity and low strength $[8,11,12,14]$.

Recently, 3D fibre-reinforced mullite, $\mathrm{ZrO}_{2}-\mathrm{SiO}_{2}$ and $\mathrm{SiO}_{2}$ composites were fabricated through the route of sol impregnation-drying-heat treatment (SIDH) using sols with high solid content (20 25 wt\%) as raw materials [15-20]. These studies indicate that SIDH route improves fabrication efficiency of solution impregnation route and reserves its advantages of homogeneous distribution of matrix and low fabrication temperature. In this study, processing, microstructures and mechanical properties of $3 \mathrm{D}$ carbon fibre-reinforced $\mathrm{Al}_{2} \mathrm{O}_{3}\left(\mathrm{C} / \mathrm{Al}_{2} \mathrm{O}_{3}\right)$ composites prepared via SIDH route were reported.

\section{Experimental}

\subsection{Raw materials and processing}

The reinforcement was 3D carbon fibre (T300 3k, ex-PAN carbon fibre, Toray) preform with a fibre volume fraction of $35 \%$ and a fibre density of $1.76 \mathrm{~g} \mathrm{~cm}^{-3}$. The structure of preform was laminated and stitched carbon fibre cloth. The raw material for matrix was an alumina sol with a 


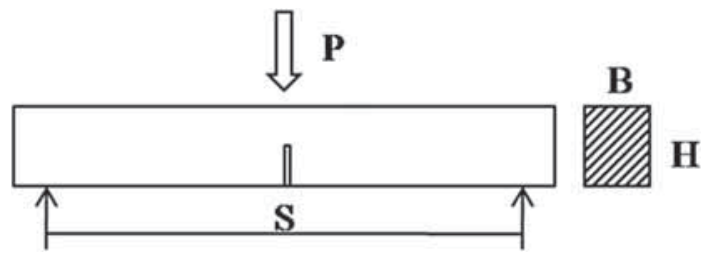

Figure 1. Sketch map of fracture toughness testing method.

solid content of $30 \mathrm{wt} \%$ and a colloid particle diameter of 20 30 nm.

Carbon fibre preform was heated at $1400^{\circ} \mathrm{C}$ for $1 \mathrm{~h}$ to remove surface size, followed by vacuum impregnation of sol. After soaked in sol for $6 \mathrm{~h}$, preform was dried at $200^{\circ} \mathrm{C}$ for $4 \mathrm{~h}$ and then, heated at preset temperature for $1 \mathrm{~h}$ in inert atmosphere with a heating rate of $10^{\circ} \mathrm{C} \mathrm{min}^{-1}$. The cycle of vacuum impregnation-drying-heat treatment was repeated to densify composites. When the weight gain of composites was $<1 \%$, the fabrication of $\mathrm{C} / \mathrm{Al}_{2} \mathrm{O}_{3}$ composites was accomplished. During densification, heat treatment was carried out at $1100^{\circ} \mathrm{C}$, if the weight gain of composites was $>3 \%$ and at $1400^{\circ} \mathrm{C}$, if the weight gain of composites was $<3 \%$.

\subsection{Characterization methods}

The gel powders that were obtained by drying sol at $200^{\circ} \mathrm{C}$ were heated at different temperatures. Then, phase composition of powders was determined by X-ray diffraction, which was carried out on a diffractometer (Bruker D8 advance) with $\mathrm{CuK} \alpha$ radiation. Data were digitally recorded during a continuous scan in the range of angle $(2 \theta)$ from 10 to $80^{\circ}$ with a scanning rate of $4^{\circ} \mathrm{min}^{-1}$. At the same time, the gel powders were cold-pressed at $120 \mathrm{MPa}$ to form wafer. After heat treatment at different temperatures, linear shrinkage and microstructure of the wafer were measured and observed.

Apparent density $\left(\rho_{\mathrm{a}}\right)$ of as-received $\mathrm{C} / \mathrm{Al}_{2} \mathrm{O}_{3}$ composites was computed from the weight-to-volume ratio. The bulk density and open porosity were measured according to Archimedes' principle with deionized water as immersion medium. The true density $\left(\rho_{\mathrm{m}}\right)$ of matrix was measured on powdered sample using a pycnometer. Then, the theoretic density $\left(\rho_{\mathrm{T}}\right)$ of $\mathrm{C} / \mathrm{Al}_{2} \mathrm{O}_{3}$ composites was calculated from the equation:

$$
\rho_{\mathrm{T}}=V_{\mathrm{f}} \times \rho_{\mathrm{f}}+V_{\mathrm{m}} \times \rho_{\mathrm{m}},
$$

where $V_{\mathrm{f}}$ and $V_{\mathrm{m}}$ are volume fractions of fibre and matrix, $\rho_{\mathrm{f}}$ and $\rho_{\mathrm{m}}$ are densities of fibre and matrix, respectively. Thus, total porosity was equal to $1-\left(\rho_{\mathrm{a}} / \rho_{\mathrm{T}}\right)$ and open porosity subtracted from total porosity gives close porosity.

The as-received $\mathrm{C} / \mathrm{Al}_{2} \mathrm{O}_{3}$ composites were annealed in high purity $\mathrm{Ar}$ atmosphere at $1600^{\circ} \mathrm{C}$ for $1 \mathrm{~h}$ to characterize its thermal stability. Three-point bending test was employed to evaluate flexural strength of composites with a span/height ratio of 15 and a cross-head speed of $0.5 \mathrm{~mm} \mathrm{~min}^{-1}$. As shown in figure 1, the notch toughness was determined by the single edge notched beam (SENB) method with a sample size of $40 \mathrm{~mm} \times 8 \mathrm{~mm}(H) \times 4 \mathrm{~mm}(B)$ and a cross-head speed of $0.05 \mathrm{~mm} \mathrm{~min}{ }^{-1}$. The span $(S)$ was $32 \mathrm{~mm}$. The notch was cut by programme-controlled diamond blade, followed by size measurement under microscope. The notch width was 0.28 $\mathrm{mm}$ and the ratio of notch depth $(a)$ to specimen height $(H)$ was 0.496 . The notch toughness $\left(K_{\mathrm{nt}}\right)$ was calculated according to the equation [21]:

$$
K_{\mathrm{nt}}=\left[(P S) / B H^{3 / 2}\right] \times f(a / H),
$$

where $f(a / H)=2.9(a / H)^{1 / 2}-4.6(a / H)^{3 / 2}+21.8(a / H)^{5 / 2}$ - 37.6 $(a / H)^{7 / 2}+38.7(a / H)^{9 / 2}$ and $P$ was the maximum load. Five specimens were tested to obtain the average flexural strength and notch toughness. Scanning electron microscopy (SEM, Quanta-200 EDAX) was employed to observe microstructures of wafers and composites.

\section{Results and discussion}

\subsection{Characteristics of sol}

Phase compositions of gel powders at various temperatures after heat treatment are presented in figure 2. Only faint diffraction peaks of $\gamma-\mathrm{Al}_{2} \mathrm{O}_{3}$ are found before $1100^{\circ} \mathrm{C}$. At $1100^{\circ} \mathrm{C}, \alpha-\mathrm{Al}_{2} \mathrm{O}_{3}$ phase which is transformed from $\gamma-\mathrm{Al}_{2} \mathrm{O}_{3}$ is detected, although its diffraction peaks are not obvious. All sharp-pointed diffraction peaks can be assigned to $\alpha-\mathrm{Al}_{2} \mathrm{O}_{3}$ phase at $1200^{\circ} \mathrm{C}$, indicating complete transformation of $\gamma-\mathrm{Al}_{2} \mathrm{O}_{3}$. Crystallization of $\alpha-\mathrm{Al}_{2} \mathrm{O}_{3}$ is enhanced with increasing the temperature to $1400^{\circ} \mathrm{C}$, as reflected by the elevated intensity and sharpness of diffraction peaks.

Linear shrinkage of gel powder wafers at various temperatures after heat treatment is shown in figure 3. A linear shrinkage of $16.8 \%$ is observed at $800^{\circ} \mathrm{C}$. This value is enlarged with increasing the temperature, displaying $18.2 \%$ at $1000^{\circ} \mathrm{C}$ and $24.3 \%$ at $1200^{\circ} \mathrm{C}$, respectively. Low crystallinity of gel powder before $1200^{\circ} \mathrm{C}$ is responsible for the high sintering activity. The obvious crystallization of $\alpha-\mathrm{Al}_{2} \mathrm{O}_{3}$ at $1200^{\circ} \mathrm{C}$ reduces sintering activity of gel powder, leading to minute increase in linear shrinkage at $1400^{\circ} \mathrm{C}(24.5 \%)$. However, the driving force for solid state sintering of $\alpha-\mathrm{Al}_{2} \mathrm{O}_{3}$ is high enough at $1600^{\circ} \mathrm{C}$. Thus, linear shrinkage is further increased to $29.2 \%$. Due to the notable sintering shrinkage, a compact fracture surface of gel powder wafer after heat treatment at $1400^{\circ} \mathrm{C}$ is observed in figure 4 . It is noted that micrometre grains bond tightly with each other, which is beneficial to mechanical properties.

\subsection{Microstructure and mechanical properties of $3 D$ $\mathrm{C} / \mathrm{Al}_{2} \mathrm{O}_{3}$ composites}

The true density $\left(\rho_{\mathrm{m}}\right)$ of the matrix was measured as $3.80 \mathrm{~g} \mathrm{~cm}^{-3}$ and the theoretic density $\left(\rho_{\mathrm{T}}\right)$ of composites was 


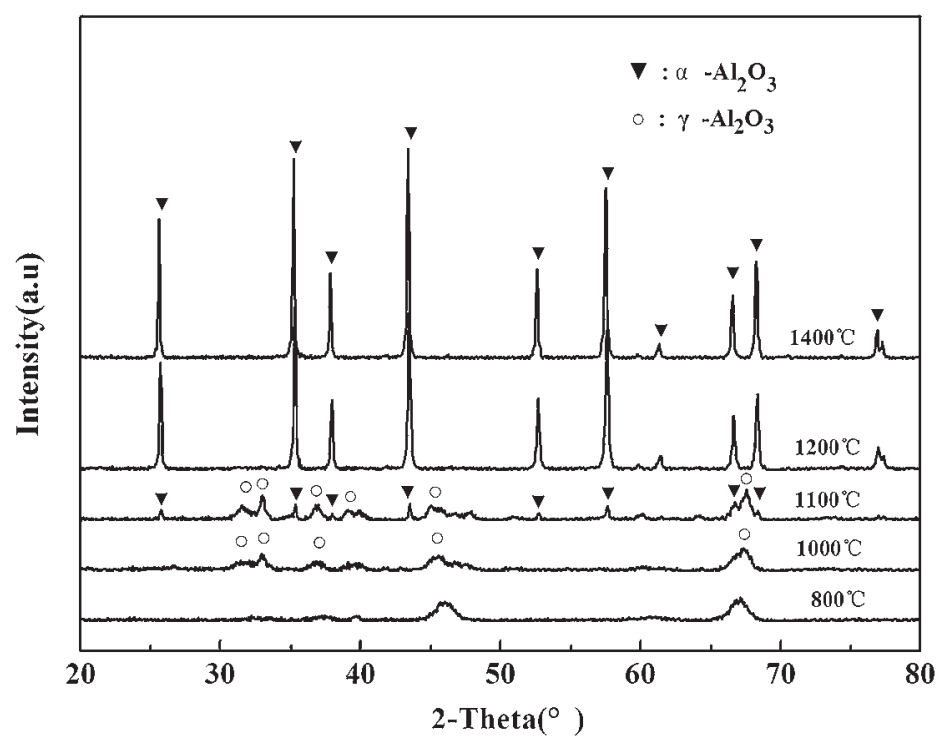

Figure 2. XRD patterns of gel powders after heat treatment at different temperatures.

calculated as $3.09 \mathrm{~g} \mathrm{~cm}^{-3}$. Thus, $\mathrm{C} / \mathrm{Al}_{2} \mathrm{O}_{3}$ composites with a total porosity of $16.8 \%$ were obtained since the apparent density of composites was measured as $2.57 \mathrm{~g} \mathrm{~cm}^{-3}$. An open porosity of $13.3 \%$ was verified by Archimedes' principle. Hence, the close porosity of composites was 3.5\%.

SEM appearances of as-received $\mathrm{C} / \mathrm{Al}_{2} \mathrm{O}_{3}$ composites are presented in figure 5. As shown, a comparatively uniform distribution of matrix is realized without large pores and cracks. The inter- and intra-bundle spaces in preform are effectively filled and the mono-fibres are well surrounded by matrix. The microstructure is formed due to low viscosity and nanometre size of sol. In early stages, it is easy for sol to impregnate into spaces in preform. Space size is reduced with increasing the density of composites. Simultaneously, the diffusion channels to space become narrow and wandering. Thus, it is more and more difficult for sol to diffuse into composites during late stages, resulting in some micropores. At the same time, microcracks are observed as a result of thermal expansion mismatch between fibre and matrix.

The flexural strength and notch toughness of as-received composites are $271.3 \pm 46.1 \mathrm{MPa}$ and $13.0 \pm 2.8 \mathrm{MPa} \mathrm{m}^{1 / 2}$, respectively. The mechanical properties are satisfying with regard to absence of interfacial coating and a total porosity of $16.8 \%$. In figure $6 \mathrm{a}$, a maximum displacement of $\sim 1.1 \mathrm{~mm}$ at invalidation point and circuitous decline of load after this point are observed. Figure 7 shows extensive fibre pull-out and long pull-out length. The non-catastrophic fracture behaviour demonstrates the prominent toughening effect of continuous fibre reinforcement.

After annealed at $1600^{\circ} \mathrm{C}$ for $1 \mathrm{~h}$ under inert atmosphere, $\mathrm{C} / \mathrm{Al}_{2} \mathrm{O}_{3}$ composites show a flexural strength of $194.1 \mathrm{MPa}$, which is $71.5 \%$ that of as-received composites. It is clear from figure $6 \mathrm{~b}$ that the annealed composites show a maximum

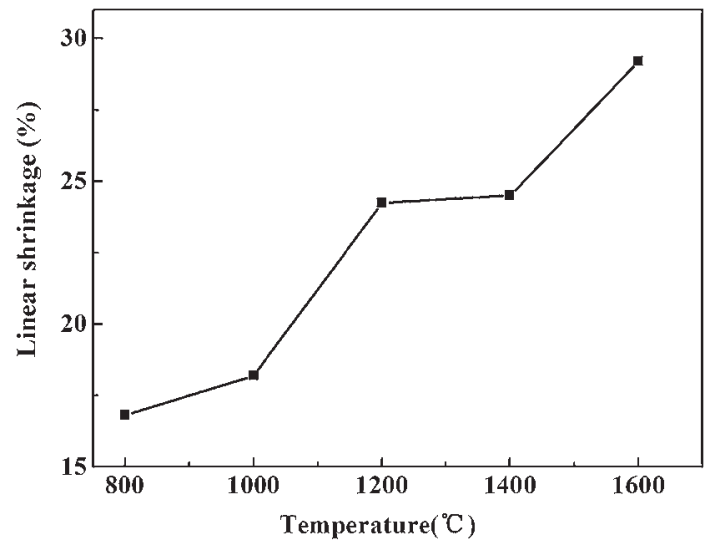

Figure 3. Linear shrinkage of gel powder wafers after heat treatment at various temperatures.

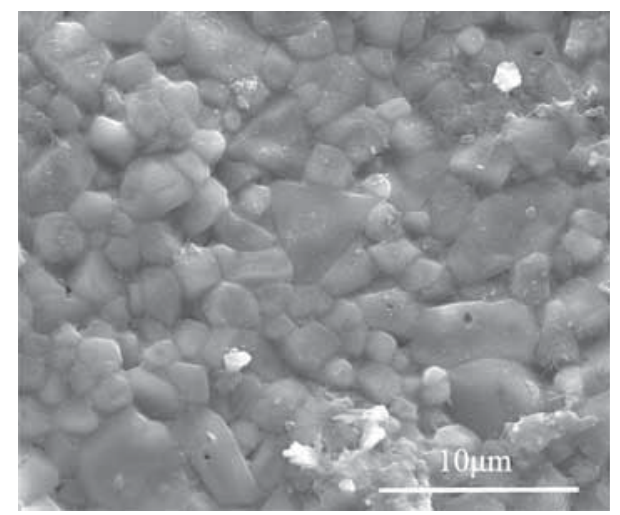

Figure 4. Fracture surface of gel powder wafer after heat treatment at $1400^{\circ} \mathrm{C}$. 

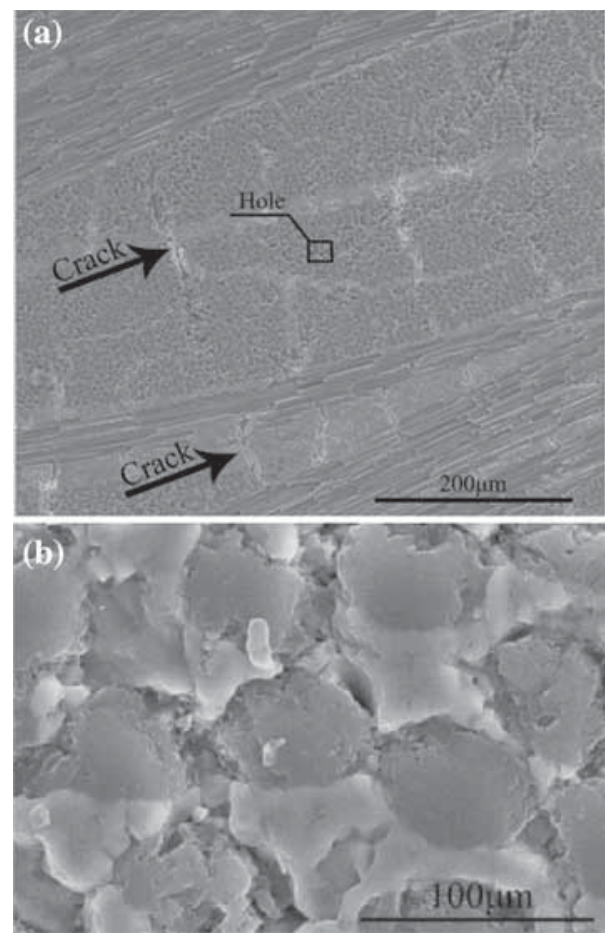

Figure 5. Cross-section morphology of as-received $\mathrm{C} / \mathrm{Al}_{2} \mathrm{O}_{3}$ composites.

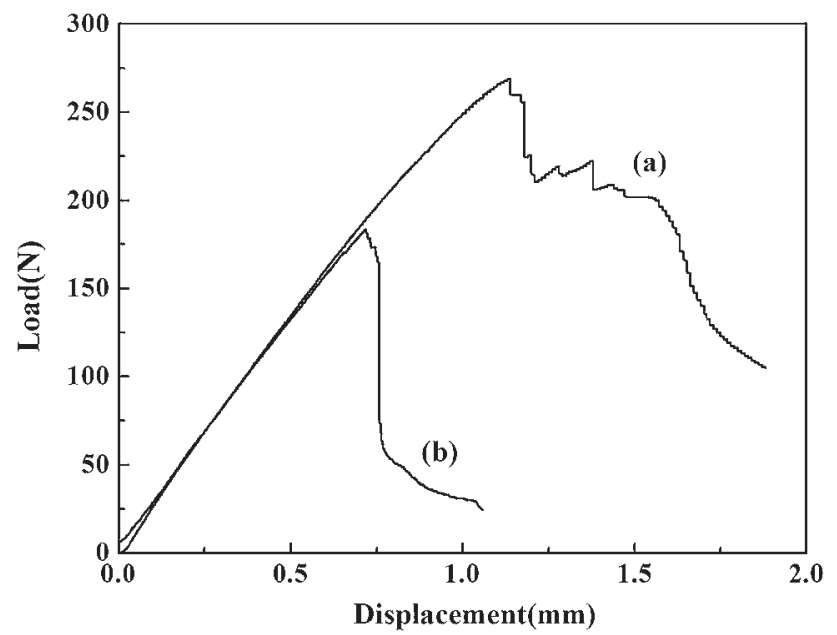

Figure 6. The representative load-displacement curves of $\mathrm{C} / \mathrm{Al}_{2} \mathrm{O}_{3}$ composites: (a) as-received and (b) after annealing.

displacement of $\sim 0.7 \mathrm{~mm}$ at invalidation point and vertical decline of load after this point. The conversion from tough to brittle fracture behaviour indicates that interfacial bonding is enhanced after heat treatment at $1600^{\circ} \mathrm{C}$.

The heat treatment at $1600^{\circ} \mathrm{C}$ promotes further sintering densification of matrix since an obvious increase of linear shrinkage from $24.5 \%$ at $1400^{\circ} \mathrm{C}$ to $29.2 \%$ at $1600^{\circ} \mathrm{C}$ is observed in figure 3 . This sintering shrinkage strengthens the physical bonding between fibre and matrix.

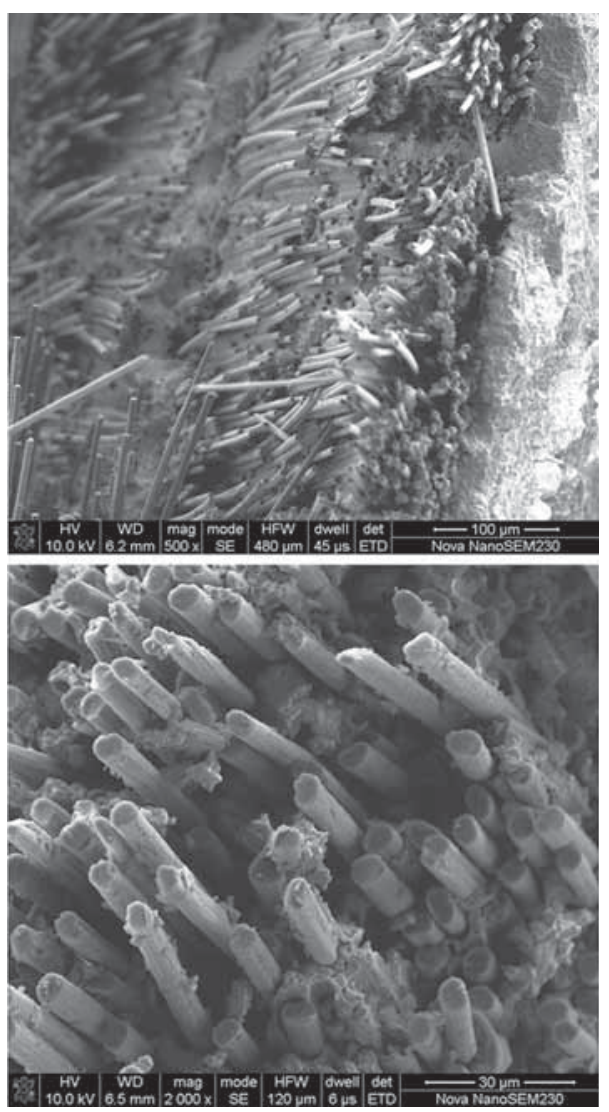

Figure 7. Fracture surface of $\mathrm{C} / \mathrm{Al}_{2} \mathrm{O}_{3}$ composites.

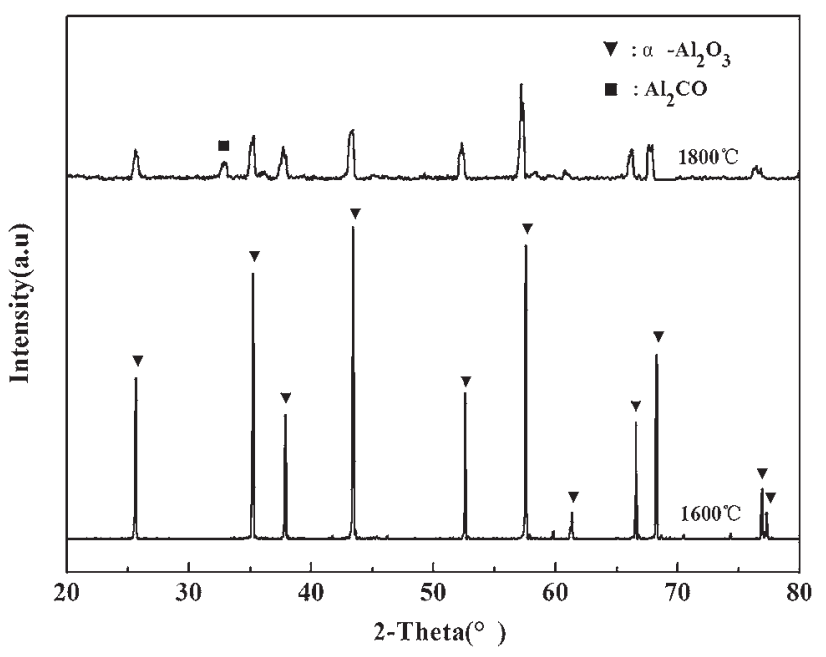

Figure 8. XRD patterns of $\mathrm{Al}_{2} \mathrm{O}_{3}$ powders after heat treatment at 1600 and $1800^{\circ} \mathrm{C}$.

When gel powder wafers were heated at $1800^{\circ} \mathrm{C}$ for $1 \mathrm{~h}$ in high purity $\mathrm{Ar}$, a new $\mathrm{Al}_{2} \mathrm{CO}$ phase is detected in figure 8 and deep dark appearance is observed in figure 9. The reaction between active carbon atmosphere in graphite furnace and $\alpha-\mathrm{Al}_{2} \mathrm{O}_{3}$, is supposed to explain this phenomenon. For $\mathrm{C} / \mathrm{Al}_{2} \mathrm{O}_{3}$ composites, it is very likely that the amorphous active carbon on fibre surface derived from decomposition 


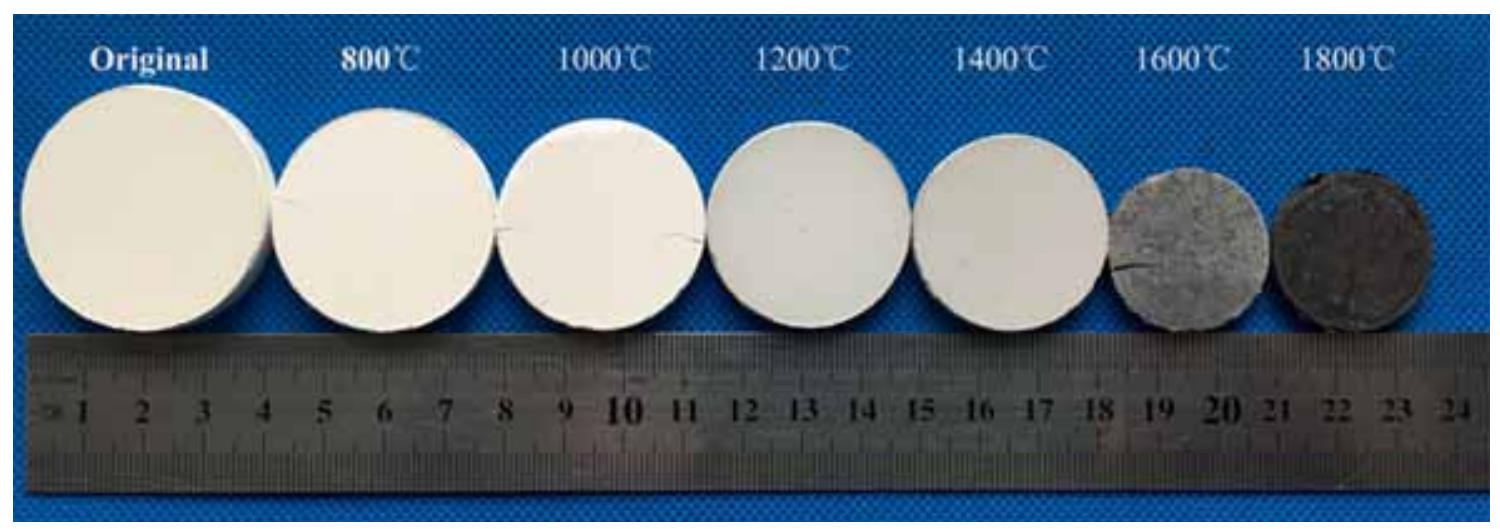

Figure 9. Optical photos of gel powder wafers after heat treatment at various temperatures.

of surface size would react with matrix at this temperature. After heat treatment at $1800^{\circ} \mathrm{C}$ for $1 \mathrm{~h}, \mathrm{C} / \mathrm{Al}_{2} \mathrm{O}_{3}$ composites showed a weight loss of only $0.77 \%$, implying a slight reaction between carbon and $\mathrm{Al}_{2} \mathrm{O}_{3}$.

At $1600^{\circ} \mathrm{C}$, a darkish wafer was obtained (figure 9) and a weight loss of $0.34 \%$ of $\mathrm{C} / \mathrm{Al}_{2} \mathrm{O}_{3}$ composites was found, suggesting occurrence of the reaction between carbon and $\mathrm{Al}_{2} \mathrm{O}_{3}$. The reaction is considered to be slighter because of the absence of $\mathrm{Al}_{2} \mathrm{CO}$ phase in figure 8 and much less weight loss. However, tensile strength loss of carbon fibre and strong interfacial bonding are created due to the slight reaction, leading to degradation in flexural strength and fracture toughness of composites. So, interfacial coating is necessary to improve mechanical properties and thermal stability of $\mathrm{C} / \mathrm{Al}_{2} \mathrm{O}_{3}$ composites. This will be focussed in subsequent studies.

\section{Conclusion}

An $\mathrm{Al}_{2} \mathrm{O}_{3}$ sol with high solid content was used to fabricate $\mathrm{C} / \mathrm{Al}_{2} \mathrm{O}_{3}$ composites. After heat treatment at $1200^{\circ} \mathrm{C}$, $\alpha-\mathrm{Al}_{2} \mathrm{O}_{3}$ with favourable sintering activity was obtained. 3D carbon fibre-reinforced $\mathrm{Al}_{2} \mathrm{O}_{3}$ composites with a total porosity of $16.8 \%$ were fabricated via vacuum impregnationdrying-heat treatment route, exhibiting $271.3 \mathrm{MPa}$ in flexural strength and $13.0 \mathrm{MPa} \mathrm{m}^{1 / 2}$ in notch toughness. After annealing at $1600^{\circ} \mathrm{C}$ for $1 \mathrm{~h}$ under inert atmosphere, $\mathrm{C} / \mathrm{Al}_{2} \mathrm{O}_{3}$ composites display degradation in flexural strength and transformation of fracture behaviour from tough to brittle mode.

\section{Acknowledgements}

This work was financially supported by the Science Innovation Foundation of Shanghai Academy of Spaceflight Technology (Grant No. SAST2015043).

\section{References}

[1] Satapathy L N and Swaroop S 2005 Bull. Mater. Sci. 28 281

[2] Mallik A K, Gangadharan S, Dutta S and Basu D 2010 Bull. Mater. Sci. 33445

[3] Tan H B, Ma X L and Fu M X 2013 Bull. Mater. Sci. 36153

[4] Zok F W 2006 J. Am. Ceram. Soc. 893309

[5] Volkmann E, Tushtev K, Koch D, Wilhelmi C, Göring J and Rezwan K 2015 Compos. Part A 6819

[6] Wilshire B and Carreño F 2000 J. Eur. Ceram. Soc. 20463

[7] Llorca J, Elices M and Celemin J A 1998 Acta Mater. 46 2441

[8] Chen Z F, Zhang L T, Cheng L F, Xu Y D and Han G F 2003 J. Inorg. Mater. 18638 (in Chinese)

[9] Colomban Ph and Wey M 1997 J. Eur. Ceram. Soc. 171475

[10] Liu H K and Lin B H 2001 Mater. Lett. 48230

[11] Chen Z F, Zhang L T, Cheng L F, Xu Y D and Xiao P $2001 \mathrm{~J}$. Aeronaut. Mater. 2128 (in Chinese)

[12] Xie Z F, Xiao J Y, Chen Z H, Wang X Y, Zheng W W and Jiang D Z 1998 J. Nat. Univ. Defense Technol. 2014 (in Chinese)

[13] Stoll E, Mahr P, Krüger H G, Kern H, Thomas B J C and Boccaccini A R 2006 J. Eur. Ceram. Soc. 261567

[14] Naskar M K, Chatterjee M, Dey A and Basu K 2004 Ceram. Int. 30257

[15] Wang Y, Liu H T, Cheng H F and Wang J 2014 Mater. Lett. 126236

[16] Wang Y, Cheng H F and Wang J 2014 Ceram. Int. 404707

[17] Wang Y, Liu H T, Cheng H F and Wang J 2013 Ceram. Int. 399229

[18] Xiang Y, Wang Q, Cao F, Ma Y W and Quan D L 2017 Ceram. Int. 43854

[19] Wang Q, Cao F, Xiang Y and Peng Z H 2017 Ceram. Int. 43 884

[20] Liu H T, Ma Q S and Liu W D 2014 Ceram. Int. 407203

[21] Guan Z D, Zhang Z T and Jiao J S 1992 (eds) Physical properties of inorganic materials (Beijing: Tsinghua University Press) (in Chinese) 